Int. J. Dev. Biol. 55: 439-445

doi: $10.1387 / \mathrm{ijdb} .103242 \mathrm{ma}$

\title{
Nervous vascular parallels: axon guidance and beyond
}

\author{
MARCO ARESE*,1,2, GUIDO SERINI ${ }^{1,2}$ and FEDERICO BUSSOLINO ${ }^{1,2}$ \\ ${ }^{1}$ Institute for Cancer Research and Treatment and \\ ${ }^{2}$ Department of Oncological Sciences, University of Torino, Candiolo, Italy
}

\begin{abstract}
The vascular and nervous systems are organized with well defined and accurate networks, which represent the anatomical structure enabling their functions. In recent years, it has been clearly demonstrated that these two systems share in common several mechanisms and specificities. For instance, the networking properties of the nervous and vascular systems are governed by common cues that in the brain regulate axon connections and in the vasculature remodel the primitive plexus towards the vascular tree. Here, we summarize the role of semaphorins as a paradigmatic example of the role of axon guidance molecules in physiological and pathological angiogenesis. Finally, we discuss the presence in blood vessels of neurexin and neuroligin, two proteins that finely modulate synaptic activity in the brain. This observation is suggestive of an intriguing new class of molecular and functional parallels between neurons and vascular cells.
\end{abstract}

KEY WORDS: semaphorin, neurexin, neuroligin

\section{Introduction}

The development of the nervous system involves progressive and regressive actions. Progressive events like neural proliferation, neurite outgrowth, and synapse formation set up a broad pattern of neural connectivity. Later in development, however, regressive events such as cell death, axon pruning, and synapse elimination are necessary to refine the pattern to more precise and mature circuitry (Low and Cheng, 2006). Vascular development displays a number of similar features. The primitive vascular plexus originated from the migrating angioblasts undergoes a profound remodeling leading to the mature vascular trees. These morphogenetic events are characterized by pruning that enables removal of redundant or misguided capillaries and by generation of new vessels programmed to differentiate into veins and arteries (Jain, 2003). The major driving force leading to these vascular rearrangements is oxygen delivery. Therefore arteries, veins and capillaries have specialized anatomical properties that allow the proper blood pressures along the vascular tree and the exchanges of nutrients and catabolites with tissues. Finally, the intercapillary distances in different organs are programmed accordingly to their partial oxygen pressure and the oxygen diffusion coefficient $(\sim 150 \mu \mathrm{m})$ (Pittman, 1995).

The similarities between vascular and nervous organogenesis appear indeed at different levels. Afirst and well established example is the role exerted by biogenic amines in neuron communication and vascular tone. More recently, common mechanisms have been envisaged at the level of cell commitment and differentiation. In vitro, cells purified from bone marrow and cord blood can originate neurons and glia (Goolsby et al., 2003; Reali et al., 2006) whereas mouse neural stem cells acquire an endothelial phenotype when co-cultured with human mature endothelial cells (Wurmser et al., 2004). In vivo, bone marrow-derived cells enter the brain and differentiate into neural cells not only in a mouse model, but also in patients that underwent bone marrow transplantation (Mezey et al., 2003). Moreover, murine neural stem cells can engraft into the hematopoietic system of irradiated hosts to produce blood (Bjornson et al., 1999) while in the quail-chick chimera model the avian cranial neuroectoderm originates smooth muscle cells (Korn et al., 2002). In addition, embryonic stem cell-derived Neuropilin-1 positive cell population differentiates in vitro towards endothelial or neural phenotypes depending upon microenvironmental cues (Gualandris et al., 2009; Noghero et al., 2010).

Finally, in the last 10 years several studies have thoroughly demonstrated that vascular cells and neurons share molecular tools and strategies during their networking (Adams and Alitalo, 2007; Carmeliet, 2003; Eichmann etal., 2005; Serini and Bussolino, 2004). Several and exhaustive reviews have focused the role of Netrin, Slit and Ephrin as axon guidance cues that function during vascular

Abbreviations used in this paper: LNS, laminin, neurexin, sex-hormone-binding protein domain; SEMA, semaphorin; EC, endothelial cells.

\footnotetext{
Final, author-corrected PDF published online: 27 July 2011.

ISSN: Online 1696-3547, Print 0214-6282

*Address correspondence to: Marco Arese. Department of Oncological Sciences, University ofTorino, Candiolo, Italy. Fax: +39-011-993-3524. e-mail: marco.arese@ @ircc.it - web: http://www.ircc.it/basicresearch/neurovascularbiology.html 
assembly (Adams and Alitalo, 2007; Adams and Eichmann, 2010; Carmeliet, 2003; Eichmann et al., 2005; Gelfand et al., 2009; Serini and Bussolino, 2004) and that of angiogenic inducers in neuronal behavior (Greenberg and Jin, 2005; Zacchigna et al., 2008). Here we summarize the more recent aspects of semaphorins (SEMA) activities in vascular remodeling and envisage a new family of common features between neurons and vascular cells based on the role exerted by the synaptic proteins neurexin and neuroligin in the vascular system.

\section{Semaphorins and vascular development}

SEMAconstitute a wide family of membrane bound and secreted guidance cues originally characterized for their ability to steer axon growth cones and then found to regulate vascular development as well (Ruiz de Almodovar et al., 2009). In vertebrates, seven different secreted class 3 SEMA (SEMA3) exist, each SEMA3 protein being assigned a letter from $A$ to $G$ (Committee, 1999). SEMA3 signal through a holoreceptor complex formed by neuropilin (Nrp) 1 or 2 and type $A$ or $D$ plexin, which respectively constitute the ligand binding and signal transducing subunit (Neufeld and Kessler, 2008). The multifaceted SEMA-elicited plexin signaling is a key regulator of cell adhesion and cytoskeletal dynamics in motile cells during neural, vascular, and epithelial morphogenesis (Jackson and Eickholt, 2009; Serini and Bussolino, 2004). Different SEMA3 can preferentially bind either Nrp1, e.g. SEMA3A, or Nrp2, for example SEMA3F, while others, such as SEMA3C, bind both Nrp1 and Nrp2 (Neufeld and Kessler, 2008). Moreover, distinct SEMA3 employ different type $A$ or type $D$ plexins to transduce their signals; for example, in neurons SEMA3A and SEMA3F principally use plexinA4 and A3 respectively (Yaron et al., 2005). PlexinD1 is the major endothelial plexin and among the different SEMA3, SEMA3E is a notable exception, since it can bind with high affinity plexinD1 (Gu et al., 2005). However, plexinD1 can also combine with either Nrp1 or Nrp2 to give rise to SEMA3 holoreceptor complexes endowed with a higher affinity than the corresponding plexinA-containing holoreceptors (Gitler et al., 2004). Furthermore, recent mutational studies (Merte et al., 2010; Nogi et al., 2010) suggest that, similarly to SEMA3E, the collapsing activity of Nrp1-bound SEMA3A also relies on its ability to interact, albeit at lower affinity, with plexins.

After a decade of studies, we are just starting to understand the mechanisms by which SEMA3 signaling can control vascular development. Indeed, this issue is complicated by the species-specific usage of different SEMA3 and by the high degree of redundancy and compensation. Zebrafish sema3a1 or sema3a2 or plxnd1 morphants display a qualitatively similar aberrant and unrestrained morphogenesis of intersegmental blood vessels, suggesting that SEMA3A via plexinD1 can exert an inhibitory effect on endothelial cell migration during vascular development (Torres-Vazquez et al., 2004). On the contrary, in sema3e morphants the sprouting of intersomitic blood vessels is severely delayed; indeed, autocrine/ paracrine Sema3e promotes endothelial cell (EC) motility likely through plexinB2 receptor (Lamont et al., 2009).

In mice, the regulation of vascular development by SEMA3 signaling appears to be different and more complex than in Zebrafish. Murine Sema3a and Sema3 $\mathrm{mRNAs}$ are enriched in endothelial tip cells of sprouting blood vessels (Strasser et al., 2010) and knockdown of Sema3a gene resulted in a defective embryonic vascular remodeling of head and trunk blood vessels in the outbred
CD-1 strain (Serini et al., 2003). Ostensibly because of genetic heterogeneity due to different maintenance this was not observed in another colony of Sema3a null CD-1 mice (Vieira et al., 2007). However, in further support for a role of SEMA3A in vascular remodeling, it has been recently reported that Sema3a deletion in an inbred strain results in defective renal vascular patterning (Reidy et al., 2009). Notably, in the same Sema3a null mice both Sema3b and Sema3e mRNA were found to be up-regulated (Reidy et al., 2009), thus providing a molecular mechanism by which compensation can occur in Sema3a null mice (Vieira et al., 2007). Indeed, both Sema3e and Plxnd1 null embryos have defects in intersomitic vessel patterning (Gitler et al., 2004; Gu et al., 2005). Nevertheless, while all PIxnd 1/- pups die shortly after birth because of life-threatening cardiovascular defects (Gitler et al., 2004; Gu et al., 2005), Sema3e null mice are viable and healthy (Bellon et al., 2010; Chauvet et al., 2007; Gu et al., 2005); suggesting that in ECs plexinD1 might convey signals not only from SEMA3E, but also from other Nrp-binding SEMA3, such as SEMA3A. Accordingly, plexinD1 is required for SEMA3A-mediated EC migration in vitro (Zhang et al., 2009) and both Sema3a (Behar et al., 1996) and Plxnd1 (Kanda et al., 2007) null embryos display similar defects in axial skeletal morphogenesis, such as rib fusion and vertebral split. Recently, a Tie2Cre-mediated gene inactivation approach showed endothelial knock down of PIxnd1 in mice causes skeletal malformations that are associated to a severe reduction of the bone marrow microvasculature (Zhang et al., 2009), strongly supporting the hypothesis that skeletal defects of PIxnd1 null mice are most likely secondary to vascular abnormalities. Since Sema3a gene deletion causes similar abnormalities in the axial skeleton (Behar et al., 1996), it will be worth studying the bone vasculature of Sema3a-/ mouse embryos as well.

A knock-in mouse strain harboring mutations that altered the SEMA3 binding ability of Nrp1 was generated (Nrp1Sema-) and reported to display neural, but not vascular patterning defects ( $\mathrm{Gu}$ et al., 2003). However, a careful analysis of some peripheral nerve projections, such as those of the ophthalmic nerve, shows that the phenotype of Nrp1Sema- knock-in mice (Gu et al., 2003) is significantly less severe than that of both Sema3a (Taniguchi et al., 1997) and Nrp1 (Gu et al., 2003; Kitsukawa et al., 1997) knockout mice. The latter observation, together with the fact that plexinD1, i.e. the main endothelial plexin, is significantly more efficient that type A plexins in increasing the affinity of Nrps for SEMA3 (Gitler et al., 2004), raises the possibility that the lack of vascular defects in Nrp1Sema-knockin mice could be due to the persistence of responsivity of ECs to SEMA3, albeit reduced if compared to that of wild type Nrp1. It will be therefore important to test the ability of Nrp1Sema- ECs to respond to Nrp1-binding SEMA3 in vitro.

\section{Semaphorins and tumor angiogenesis}

The capacity of semaphorins to regulate vessel patterning is particularly relevant to cancer progression and in general to the altered vascularization occurring, for example, in chronic inflammation. SEMA3 emerge as promising targets for cancer therapy. Indeed, molecules belonging to this class of chemorepulsive agents can display a direct effect of both on tumor cells; e.g. SEMA3F inhibits the growth of a wide range of xenograft cancer models (Neufeld and Kessler, 2008; Potiron et al., 2007), and on ECs, e.g. SEMA3A and SEMA3F repel ECs and inhibit their migration promoted by 
angiogenic inducers (Bielenberg et al., 2004; Futamura et al., 2007; Kessler et al., 2004; Serini et al., 2003). Several SEMA3, including SEMA3A and SEMA3F, are expressed by ECs, suggesting that they may function in an autocrine fashion. This autocrine production of chemorepulsive SEMA3 molecules is balanced by the autocrine production of angiogenic inducers, with the final results of a proper vessel navigation and shape (Serini et al., 2008). An imbalance in the ratio of autocrine VEGF-A/SEMA3 in ECs might happen during tumor progression and contribute to the structural and functional defects observed in tumor blood vessels (Jain, 2008). By studying two mouse transgenic models of carcinogenesis, namely Rip-Tag insulinoma model and K14-HPV16/E2 uterine cervix carcinoma as well as patients affected by aggressive multiple myelomas (Maione et al., 2009; Vacca et al., 2006), we observed that such an homeostatic balance can be disrupted due to a dramatic drop in the production of SEMA3 by tumor ECs. Importantly, we found that the reintroduction of SEMA3A caused marked endothelial apoptosis, significant reduction in vessels density and branching, enhancement of pericyte coverage and reduction of tumor tissue hypoxia (Maione et al., 2009). Of note, the normalizing activity exerted by SEMA3A on tumor blood vessels is similar, but apparently longer lasting than that observed upon VEGF-A inhibition (Jain, 2005). Interestingly, another member of SEMA class 3, SEMA3E, inhibits tumor angiogenesis and the growth of primary tumor, but it favors metastasis spreading (Casazza et al., 2010). In addition, SEMAs other than SEMA3 has been found to modulate tumor angiogenesis. For instance, SEMA4D behaves as a pro-angiogenic factor (Basile et al., 2005; Basile et al., 2007; Conrotto et al., 2005; Sierra et al., 2008) which is also involved in tumor progression. In particular, it has been reported that tumor growth is significantly impaired in mice lacking Sema4D (Sierra et al., 2008); tumor associated macrophages constitutes a major source of Sema4D that is required for proper vessel maturation in tumors.

\section{Neurexin and neuroligin: synaptic proteins tackle vas- culature}

It was recently discovered (Bottos et al., 2009) that various isoforms of the essential synaptic proteins neurexins and neuroligins are expressed by cells of the vascular wall (endothelial and smooth muscle cells). In this context, in analogy to the brain, they are modified by alternative splicing and reciprocally interact. Moreover, an antibody against a specific isoform of neurexin (anti- $\beta$ NRXN) inhibits vascular remodeling/angiogenesis, whereas the overexpression of neuroligin in ECs placed in a tumorigenic environment induces vessel growth in the chicken chorioallantoic membrane. As an insight into its mechanism of action it was demonstrated that anti- $\beta$ NRXN modulates vascular tone of isolated arteries by reducing vessel tension induced by noradrenalin.

Neurexins and neuroligins are transmembrane proteins that are codified respectively by three and five genes in humans (BoIliger et al., 2001; Tabuchi and Sudhof, 2002). Both gene families present a high degree of evolutionary conservation that can be explained by the action of a positive selective pressure which in turn suggests a conservation of their functions across vertebrate evolution (Rissone et al., 2007; Rissone et al., 2010)

Neurexins, which are produced as a long $(\alpha)$ and a short $(\beta)$ forms by each of their genes, have been widely studied because of their exceptionally extended alternative splicing (Rissone et al., 2007; Tabuchi and Sudhof, 2002) and have been indirectly localized at the pre-synaptic membrane (Sudhof, 2001). Thousands of different isoforms were predicted to be produced by the three mammalian neurexin genes, so that they were proposed as molecular codes for the specific reciprocal neuronal recognition (Missler and Sudhof, 1998). Neuroligins are less subjected to alternative splicing, are localized at the post-synaptic membrane (Song et al., 1999) and interact with neurexins from the opposite

post-synaptic side

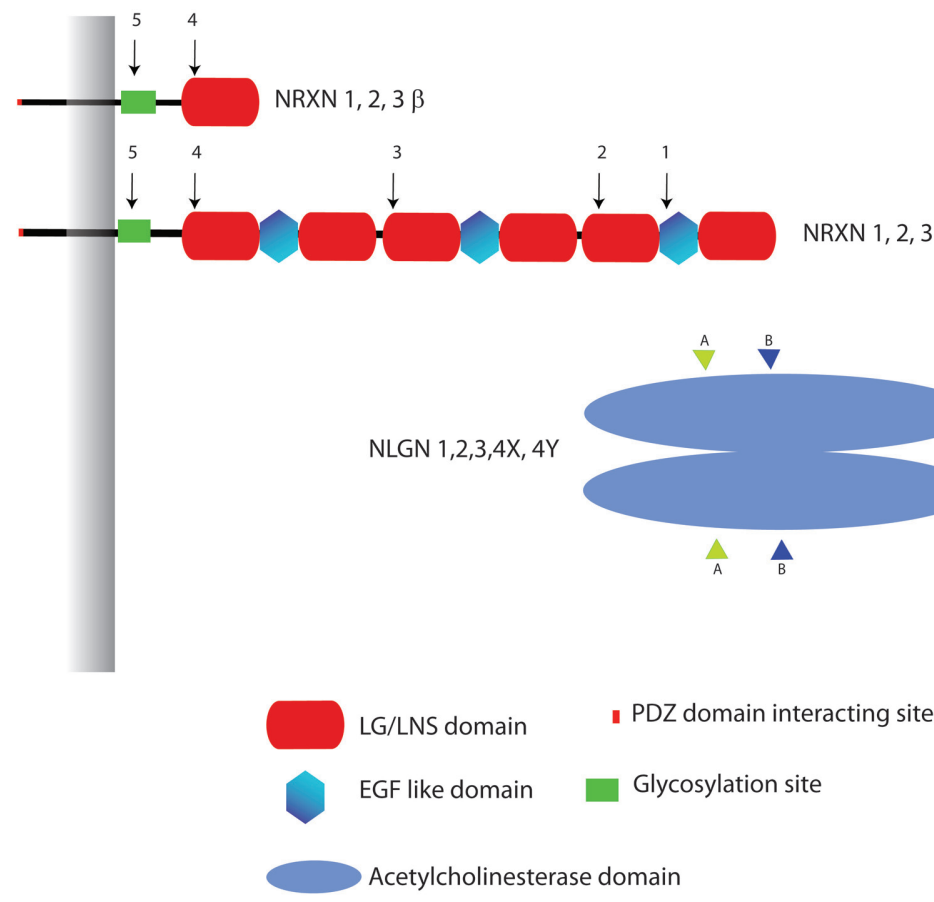

Fig. 1. Domain structures and synaptic arrangement of neurexin and neuroligin. There are three neurexin genes in mammals, each of which has both an upstream promoter that is used to generate the larger $\alpha$-neurexins and a downstream promoter that is used to generate the $\beta$-neurexins. Alternative splicing at five sites (arrows 1 to 5) and $\mathrm{N}$ - and $\mathrm{O}$-glycosylation contribute additional diversity. $\beta$-Neurexins contain a single LNS domain (laminin, neurexin, sex-hormone-binding protein domain; also known as a Laminin G, LG, domain), whereas $\alpha$-neurexins contain six LNS domains organized into modules with three EGF-like domains. There are five neuroligin genes in humans: NLGN1, NLGN2, NLGN3, NLGN4 and NLGN4Y The major extracellular domain of neuroligins, which contains two potential splicing sites ( $A$ and $B$ ), is homologous to acetylcholinesterase but lacks cholinesterase activity and mediates binding to neurexins. Cytosolic tail of both neurexin and neuroligin contains a PDZ (Post synaptic density protein (PSD95), Disc large tumor suppressor, DIgA and Zonula occludens-1 protein, zo-1, domain) binding site. Neuroligin is presented as a dimer, which represents its normal functional conformation. 
side (in trans) of the synaptic cleft in a calcium-dependent manner (Nguyen and Sudhof, 1997) (Fig. 1).

Both neurexins and neuroligins display a strong and selective synapse formation-promoting activity in vitro (Graf et al., 2004; Scheiffele et al., 2000). Nonetheless, knocking down the expression of the three $\alpha$ forms of neurexins (Missler, 2003) or neuroligins 1-3 (Varoqueaux, 2006) in mouse shows that these proteins have fundamental functions that reside in the modulation of synaptic transmission more than in the early adhesive steps of synapse formation. The same studies reveal a redundancy of function between isoforms of the same gene family. Altogether, neurexin and neuroligin are part of a large set of Synaptic Cell Adhesion Molecules (SCAMs) whose elimination in mice surprisingly results in an overall maintenance of synaptic structure (Piechotta et al., 2006), while affecting their functions.

Albeit with a number of open questions, both neurexin and neuroligin have been involved in the pathogenesis of autism spectrum disorders (ASDs) (Sudhof, 2008). Neuroligins were the first to be implicated in this disease when it was found that the $X$ linked genes NLGL4 and NLGN3 contained point mutations in affected individuals (Jamain, 2003). The role of neurexins in autism susceptibility was widely reported in the following years (Feng, 2006; Kim, 2008; Szatmari et al., 2007). Finally, SHANK3, a downstream intracellular scaffolding protein that binds indirectly to neuroligin through PSD95 and GKAP (Sheng and Hoogenraad, 2007) has been involved in ASDs (Durand, 2007; Marshall, 2008; Wilson, 2003).

\section{Why synaptic proteins on blood vessels?}

Although very appealing, the finding of neurexin and neuroligin in blood vessels poses important conceptual challenges, mostly because synaptic activity appears distant from the vascular functions. As a matter of fact, unlike many of the proteins that mediate axon or vessel guidance, the neuronal role of neurexin and neuroligin cannot easily be linked to any of the most characterized cellular events of angiogenesis (proliferation, adhesion, or migration).

Which are the possible roles of these two synaptic proteins

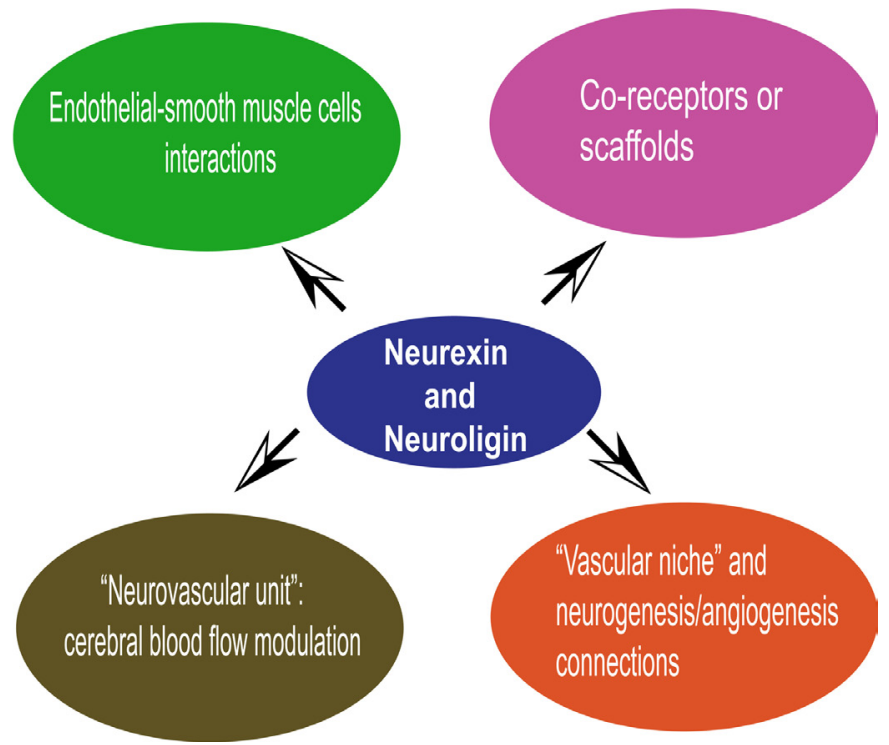

Fig. 2. Workig hypotheses regarding the role of neurexins and neuroligins in the vascular systems. in the vascular context (Fig. 2)? The neurexin/neuroligin protein families are very complex and achieving a gratifying answer to this question will take time and different approaches. However, the data can be looked at from two perspectives.

The first is the role that neurexin and neuroligin can have during the growth and remodeling of the vascular system itself. In this context it should be noted that, although $\beta$ neurexin null mice are not yet available, no vascular defects have been described for mice carrying null mutations within the three $\alpha$ neurexin (Missler, 2003) or the three neuroligins (Varoqueaux, 2006) genes. Therefore, though dedicated studies are needed, to date, the most direct approaches aimed at illustrating the functions of these proteins have not been informative. The following working hypotheses and reflections can be introduced: i) in analogy to the synaptic environment (Piechotta et al., 2006), a redundant collection of adhesive proteins (that never perform pure "adhesive" functions) including neurexins and neuroligins, is at work to finely regulate blood vessels functions; ii) neurexins and neuroligins, which are crucially found in association in both nervous and vascular systems, could also work separately, because of the much higher amount of neuroligin that is expressed in blood vessels and the fact that neuroligin coprecipitates specifically with $\beta$ neurexins and not with $\alpha$ neurexins (Bottos et al., 2009), that can remain "orphans"; iii) these proteins, as other neuronal cues (Neufeld and Kessler, 2008), could exploit the molecular machinery of key regulators of vascular physiology (e.g. members of the VEGF/KDR andAngiopoieitn/Tie-2 families) to achieve their specific functions, by acting as coreceptors or scaffold proteins; iv) similarly, vascular proteins that are identical or have homologous counterparts to the known nervous protein partners of neurexins and neuroligins (for example dystroglycan (Sugita, 2001), ion channels (Missler, 2003) or intracellular PDZ domain rich proteins) are good candidates for molecular and functional studies. Another possibility stems from the observation that during vascular development both endothelial and vascular smooth muscle cells express neurexin and neuroligin (Fig. 3). In mature vessels, however, neurexin and neuroligin tend to segregate respectively in smooth muscle cells and in endothelium (Bottos et al., 2009), suggesting that they play a role in the formation of vascular layers.

The second point of view relates to the possibility that neurexins and neuroligins mediate part of the physical cross talk between neurons and blood vessels. These events could take place in very different settings and timings. One is the recognition/adhesion between the axon terminals (varicosities) and the target region of the blood vessels that takes place in the final phase of the autonomic innervation of the vascular system (Glebova and Ginty, 2005). These cell-to-cell adhesive events would be temporary, since, normally, the varicosities are located at a certain distance from the smooth muscle layer (Burnstock, 2008). An additional fascinating possibility is that neurexin and neuroligin mediate the interactions between the nervous and vascular system during angiogenesis/ synaptogenesis/neurogenesis phenomena that take place in the cerebellum and hippocampus upon repetitive physical activities and/or motor skill learning (Isaacs et al., 1992; Van der Borght et al., 2009). Neurexin-neuroligin mediated cross talk between blood vessels and neuronal cells could be at play also in the so called "vascular niche" of the subgranular zone (SGZ) of the hippocampus where neuronal precursors are in intimate contact with the blood vessels (reviewed in (Doetsch, 2003)). As a final point, the widespread expression of neurexin and neuroligin in the vessels 
$\mathbf{L}$

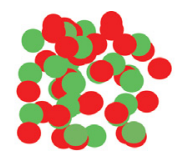

Embryonic vessel

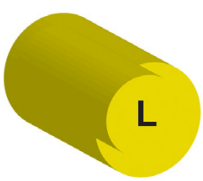

Neuroligin

$\mathbf{L}$

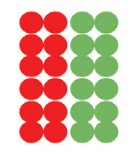

Neurexin

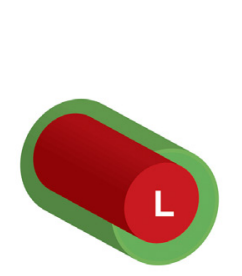

Mature vessel

Overlay

Fig. 3. Expression of neurexin and neuroligin during blood vessel assembly (for details see text). L stands for Luminal side of blood vessel.

of the brain parenchyma (Bottos et al., 2009), indicates that they could mediate a pervasive interaction between the vasculature and the surrounding neural tissue. They could indeed be part of the so called "neurovascular unit" that matches the cerebral blood flow to the metabolic demands of neurons (Drake and ladecola, 2007). In this last circumstance, neurexin and neuroligin would have a double relations with autism spectrum disorders. In fact, cerebral temporal regions that are implicated in social perception, language, and theory-of-mind (abilities that are impaired in autism) can undergo hypoperfusion in autistic children (Ohnishi et al., 2000; Zilbovicius et al., 2000). In the same way, significant negative correlation has been observed between rCBF (Regional Cerebral Blood Flow) in the left superior temporal gyrus and the diagnostic score for autism ADI-R. The more severe the autistic syndrome, the more rCBF is low in this region, suggesting that left superior temporal hypoperfusion is related to autistic behavior severity (Gendry Meresse et al., 2005). These last observations are particularly intriguing when related to the involvement of $\beta$ neurexin in vessel tone maintenance (Bottos et al., 2009).

In conclusion, can we predict a general significance of the synaptic/vascular parallels? Obviously, the capacity to form billions of specific and plastic cell-to-cell contacts through the synapses represents the most fascinating anatomical and biochemical features of the nervous system, and the enormous heterogeneity of neurexins and neuroligins matches this perspective perfectly. While the task of forming and operating such a network is enormously complex, blood vessels do not appear to have the same needs. However, as in many other instances, we should consider that nature saves its resources by using the same molecules or molecular arrangements with different purposes, while complex and specific functions can be built upon molecular "mixing". For example, it is an established fact that the proteins positioned at the proximal intracellular side of tight junctions (typical of endothelial and epithelial linings) and those at synapses display a similar domain organization and build up comparable scaffolding structures (Bottos et al., 2009; Butz et al., 1998; Dejana, 2004).

Alternativey, we should not exclude that the vascular system embraces processes unknown at this time or underestimated in their complexity. As a matter of fact blood vessels are highly heterogeneous (Aird, 2006) and perform a multitude of tasks, some of which require fine cell-to-cell recognition events (e.g. leukocyte extravasation (Vestweber, 2002)). In conclusion, it is very likely that the discovery of neurexin and neuroligin in the vascular system will fuel new concepts into the field.

\section{Acknowledgment}

This work was supported by grant of Associazione Italiana per la Ricerca sul Cancro (IG \#10133) (to F.B.), (IG \# 9211) (to G.S.); Telethon Italy (GGP04127 and GGP09175) (to G.S.); Compagnia di San Paolo - Neuroscience Program Multicentre Projects (to G.S.); Fondazione Piemontese per la Ricerca sul Cancro - ONLUS - Intramural Grant 2010 (to G.S.); Ministero della Salute - Programma Ricerca Oncologica 2006 and Ricerca Finalizzata 2006 (to G.S. and F.B.), Associazione Augusto per la Vita (G.S.); Regione Piemonte (Finalized Health Research 2006, 2008 and 2009; Industrial Research and Precompetitive Development 2006: grants PRESTO and SPLASERBA; Technological Platforms for Biotechnology: grant DRUIDI; Converging Technologies: grant PHOENICS; Industrial Research 2009: grant BANP) (to F.B. and G.S.).; CRT Foundation (to F.B.).

\section{References}

ADAMS, R.H. and ALITALO, K. (2007). Molecular regulation of angiogenesis and lymphangiogenesis. Nat Rev Mol Cell Biol. 8: 464-478.

ADAMS, R.H. and EICHMANN, A. (2010). Axon guidance molecules in vascular patterning. Cold Spring Harb Perspect Biol 2: a001875.

AIRD, W.C. (2006). Mechanisms of endothelial cell heterogeneity in health and disease. Circ Res 98: 159-162.

BASILE, J.R., AFKHAMI, T. and GUTKIND, J.S. (2005). Semaphorin 4D/plexin-B1 induces endothelial cell migration through the activation of PYK2, Src, and the phosphatidylinositol 3-kinase-Akt pathway. Mol Cell Biol 25: 6889-6898.

BASILE, J.R., GAVARD, J. and GUTKIND, J.S. (2007). Plexin-B1 Utilizes RhoA and Rho Kinase to Promote the Integrin-dependent Activation of Akt and ERK and Endothelial Cell Motility. J Biol Chem 282: 34888-93485.

BEHAR, O., GOLDEN, J.A., MASHIMO, H., SCHOEN, F.J. and FISHMAN, M.C. (1996). Semaphorin III is needed for normal patterning and growth of nerves, bones and heart. Nature 383: 525-528.

BELLON, A., LUCHINO, J., HAIGH, K., ROUGON, G., HAIGH, J., CHAUVET, S. and MANN, F. (2010). VEGFR2 (KDR/Flk1) signaling mediates axon growth in response to semaphorin 3E in the developing brain. Neuron 66: 205-219.

BIELENBERG, D.R., HIDA, Y., SHIMIZU, A., KAIPAINEN, A., KREUTER, M., KIM, C.C. and KLAGSBRUN, M. (2004). Semaphorin 3F, a chemorepulsant for endothelial cells, induces a poorly vascularized, encapsulated, nonmetastatic tumor phenotype. J Clin Invest 114: 1260-1671.

BJORNSON, C.R., RIETZE, R.L., REYNOLDS, B.A., MAGLI, M.C. and VESCOVI, A.L. (1999). Turning brain into blood: a hematopoietic fate adopted by adult neural stem cells in vivo. Science 283: 534-537.

BOLLIGER, M.F., FREI, K., WINTERHALTER, K.H. and GLOOR, S.M. (2001). Identification of a novel neuroligin in humans which binds to PSD-95 and has a widespread expression. Biochem J 356: 581-588.

BOTTOS, A., DESTRO, E., RISSONE, A., GRAZIANO, S., CORDARA, G., ASSENZIO, B., CERA, M.R., MASCIA, L., BUSSOLINO, F. and ARESE, M. (2009). The synaptic proteins neurexins and neuroligins are widely expressed in the vascular system and contribute to its functions. Proc NatIAcad SciUSA. 106:20782-20787.

BURNSTOCK, G. (2008). Non-synaptic transmission at autonomic neuroeffector junctions. Neurochem Int 52: 14-25.

BUTZ, S., OKAMOTO, M. and SUDHOF, T.C. (1998). A tripartite protein complex with the potential to couple synaptic vesicle exocytosis to cell adhesion in brain. Cell 94: 773-782.

CARMELIET, P. (2003). Blood vessels and nerves: common signals, pathways and diseases. Nat Rev Genet 4: 710-720.

CASAZZA, A., FINISGUERRA, V., CAPPARUCCIA, L., CAMPERI, A., SWIERCZ, 
J.M., RIZZOLIO, S., ROLNY, C., CHRISTENSEN, C., BERTOTTI, A., SAROTTO, I. et al.(2010) Sema3E-Plexin D1 signaling drives human cancer cell invasiveness and metastatic spreading in mice. J Clin Invest 120: 2684-2698.

CHAUVET, S., COHEN, S., YOSHIDA, Y., FEKRANE, L., LIVET, J., GAYET, O., SEGU, L., BUHOT, M.C., JESSELL, T.M., HENDERSON, C.E. et al., (2007). Gating of Sema3E/PlexinD1 signaling by neuropilin-1 switches axonal repulsion to attraction during brain development. Neuron 56: 807-822.

COMMITTEE, S.N. (1999). Unified nomenclature for the semaphorins/collapsins. Cell 97: 551-552.

CONROTTO, P., VALDEMBRI, D., CORSO, S., SERINI, G., TAMAGNONE, L., COMOGLIO, P.M., BUSSOLINO, F. and GIORDANO, S. (2005). Sema4D induces angiogenesis through Met recruitment by Plexin B1. Blood 105: 4321-4329.

DEJANA, E. (2004). Endothelial cell-cell junctions: happy together. Nat Rev Mol Cell Biol 5: 261-270.

DOETSCH, F. (2003). A niche for adult neural stem cells. Curr Opin Genet Dev 13: 543-550.

DRAKE, C.T. and IADECOLA, C. (2007). The role of neuronal signaling in controlling cerebral blood flow. Brain Lang 102: 141-152.

DURAND, C.M. (2007). Mutations in the gene encoding the synaptic scaffolding protein SHANK3 are associated with autism spectrum disorders. Nature Genet. 39:25-37.

EICHMANN, A., LE NOBLE, F., AUTIERO, M. and CARMELIET, P. (2005). Guidance of vascular and neural network formation. Curr Opin Neurobiol 15: 108-115.

FENG, J. (2006). High frequency of neurexin 1[beta] signal peptide structural variants in patients with autism. Neurosci. Lett. 409: 10-13.

FUTAMURA, M., KAMINO, H., MIYAMOTO, Y., KITAMURA, N., NAKAMURA, Y., OHNISHI, S., MASUDA, Y. and ARAKAWA, H. (2007). Possible role of semaphorin $3 \mathrm{~F}$, a candidate tumor suppressor gene at 3p21.3, in p53-regulated tumor angiogenesis suppression. Cancer Res 67: 1451-1460.

GELFAND, M.V., HONG, S. and GU, C. (2009). Guidance from above: common cues direct distinct signaling outcomes in vascular and neural patterning. Trends Cell Biol 19: 99-110.

GENDRY MERESSE, I., ZILBOVICIUS, M., BODDAERT, N., ROBEL, L., PHILIPPE, A., SFAELLO, I., LAURIER, L., BRUNELLE, F., SAMSON, Y., MOUREN, M.C. et al., (2005). Autism severity and temporal lobe functional abnormalities. Ann Neurol 58: 466-469

GITLER, A.D., LU, M.M. and EPSTEIN, J.A. (2004). PlexinD1 and semaphorin signaling are required in endothelial cells for cardiovascular development. Dev Cell 7: 107-116.

GLEBOVA, N.O. and GINTY, D.D. (2005). Growth and survival signals controlling sympathetic nervous system development. Annu Rev Neurosci 28: 191-222.

GOOLSBY, J., MARTY, M.C., HELETZ, D., CHIAPPELLI, J., TASHKO, G., YARNELL, D., FISHMAN, P.S., DHIB-JALBUT, S., BEVER, C.T., JR., PESSAC, B. et al., (2003). Hematopoietic progenitors express neural genes. Proc Natl Acad Sci USA 100: 14926-14931.

GRAF, E.R., ZHANG, X., JIN, S.X., LINHOFF, M.W. and CRAIG, A.M. (2004). Neurexins induce differentiation of GABA and glutamate postsynaptic specializations via neuroligins. Cell 119: 1013-1026.

GREENBERG, D.A. and JIN, K. (2005). From angiogenesis to neuropathology. Nature 438: 954-959.

GU, C., RODRIGUEZ, E.R., REIMERT, D.V., SHU, T., FRITZSCH, B., RICHARDS, L.J., KOLODKIN, A.L. and GINTY, D.D. (2003). Neuropilin-1 conveys semaphorin and VEGF signaling during neural and cardiovascular development. Dev Cell5: 45-57.

GU, C., YOSHIDA, Y., LIVET, J., REIMERT, D.V., MANN, F., MERTE, J., HENDERSON, C.E., JESSELL, T.M., KOLODKIN, A.L. and GINTY, D.D. (2005). Semaphorin $3 \mathrm{E}$ and plexin-D1 control vascular pattern independently of neuropilins. Science 307: 265-268.

GUALANDRIS, A., NOGHERO, A., GEUNA, M., ARESE, M., VALDEMBRI, D., SERINI, G. and BUSSOLINO, F. (2009). Microenvironment drives the endothelial or neural fate of differentiating embryonic stem cells coexpressing neuropilin-1 and Flk-1. FASEB J 23: 68-78.

ISAACS, K.R., ANDERSON, B.J., ALCANTARA, A.A., BLACK, J.E. and GREENOUGH, W.T. (1992). Exercise and the brain: angiogenesis in the adult rat cerebellum after vigorous physical activity and motor skill learning. J Cereb Blood Flow Metab 12: 110-119.

JACKSON, R.E. and EICKHOLT, B.J. (2009). Semaphorin signalling. Curr Biol 19: R504-R507.
JAIN, R.K. (2003). Molecular regulation of vessel maturation. Nat Med 9: 685-693.

JAIN, R.K. (2005). Normalization of tumor vasculature: an emerging concept in antiangiogenic therapy. Science 307: 58-62.

JAIN, R.K. (2008). Lessons from multidisciplinary translational trials on anti-angiogenic therapy of cancer. Nat Rev Cancer 8: 309-316.

JAMAIN, S. (2003). Mutations of the X-linked genes encoding NIgns NLGN3 and NLGN4 are associated with autism. Nature Genet. 34: 27-29.

KANDA, T., YOSHIDA, Y., IZU, Y., NIFUJI, A., EZURA, Y., NAKASHIMA, K. and NODA, M. (2007). PlexinD1 deficiency induces defects in axial skeletal morphogenesis. $J$ Cell Biochem 101: 1329-1337.

KESSLER, O., SHRAGA-HELED, N., LANGE, T., GUTMANN-RAVIV, N., SABO, E., BARUCH, L., MACHLUF, M. and NEUFELD, G. (2004). Semaphorin-3F is an inhibitor of tumor angiogenesis. Cancer Res 64: 1008-1015.

KIM, H.G. (2008). Disruption of neurexin 1 associated with autism spectrum disorder. Am. J. Hum. Genet. 82: 199-207.

KITSUKAWA, T., SHIMIZU, M., SANBO, M., HIRATA, T., TANIGUCHI, M., BEKKU, Y., YAGI, T. and FUJISAWA, H. (1997). Neuropilin-semaphorin III/D-mediated chemorepulsive signals play a crucial role in peripheral nerve projection in mice. Neuron 19: 995-1005.

KORN, J., CHRIST, B. and KURZ, H. (2002). Neuroectodermal origin of brain pericytes and vascular smooth muscle cells. J Comp Neurol 442: 78-88.

LAMONT, R.E., LAMONT, E.J. and CHILDS, S.J. (2009). Antagonistic interactions among Plexins regulate the timing of intersegmental vessel formation. Dev Biol 331: 199-209.

LOW, L.K. and CHENG, H.J. (2006). Axon pruning: an essential step underlying the developmental plasticity of neuronal connections. Philos Trans $R$ Soc Lond $B$ Biol Sci 361: 1531-1544.

MAIONE, F., MOLLA, F., MEDA, C., LATINI, R., ZENTILIN, L., GIACCA, M., SEANO G., SERINI, G., BUSSOLINO, F. and GIRAUDO, E. (2009). Semaphorin 3A is an endogenous angiogenesis inhibitor that blocks tumor growth and normalizes tumor vasculature in transgenic mouse models. J Clin Invest 119: 3356-3372.

MARSHALL, C.R. (2008). Structural variation of chromosomes in autism spectrum disorder. Am. J. Hum. Genet. 82: 477-488.

MERTE, J., WANG, Q., VANDER KOOI, C.W., SARSFIELD, S., LEAHY, D.J., KOLODKIN, A.L. and GINTY, D.D. (2010). A forward genetic screen in mice identifies Sema3A(K108N), which binds to neuropilin-1 but cannot signal. J Neurosci 30 : 5767-5775.

MEZEY, E., KEY, S., VOGELSANG, G., SZALAYOVA, I., LANGE, G.D. and CRAIN, B. (2003). Transplanted bone marrow generates new neurons in human brains. Proc Natl Acad Sci USA 100: 1364-1369.

MISSLER, M. (2003). [alpha]-Neurexins couple Ca2+ channels to synaptic vesicle exocytosis. Nature 423: 939-948.

MISSLER, M. and SUDHOF, T.C. (1998). Neurexins: three genes and 1001 products. Trends Genet 14: 20-26.

NEUFELD, G. and KESSLER, O. (2008). The semaphorins: versatile regulators of tumour progression and tumour angiogenesis. Nat Rev Cancer 8: 632-645.

NGUYEN, T. and SUDHOF, T.C. (1997). Binding properties of neuroligin 1 and neurexin 1 beta reveal function as heterophilic cell adhesion molecules. $J$ Biol Chem 272: 26032-26039.

NOGHERO, A., BUSSOLINO, F. and GUALANDRIS, A. (2010). Role of the microenvironment in the specification of endothelial progenitors derived from embryonic stem cells. Microvasc Res 79: 178-183.

NOGI, T., YASUI, N., MIHARA, E., MATSUNAGA, Y., NODA, M., YAMASHITA, N. TOYOFUKU, T., UCHIYAMA, S., GOSHIMA, Y., KUMANOGOH, A. et al., (2010). Structural basis for semaphorin signalling through the plexin receptor. Nature 467: 1123-1127.

OHNISHI, T., MATSUDA, H., HASHIMOTO, T., KUNIHIRO, T., NISHIKAWA, M., UEMA T. and SASAKI, M. (2000). Abnormal regional cerebral blood flow in childhood autism. Brain 123: 1838-4184.

PIECHOTTA, K., DUDANOVA, I. and MISSLER, M. (2006). The resilient synapse: insights from genetic interference of synaptic cell adhesion molecules. Cell Tissue Res 326: 617-642.

PITTMAN, R.N. (1995). Influence of microvascular architecture on oxygen exchange in skeletal muscle. Microcirculation 2: 1-18.

POTIRON, V.A., SHARMA, G., NASARRE, P., CLARHAUT, J.A., AUGUSTIN, H.G., 
GEMMILL, R.M., ROCHE, J. and DRABKIN, H.A. (2007). Semaphorin SEMA3F affects multiple signaling pathways in lung cancer cells. Cancer Res67:8708-8715.

REALI, C., SCINTU, F., PILLAI, R., CABRAS, S., ARGIOLU, F., RISTALDI, M.S., SANNA, M.A., BADIALI, M. and SOGOS, V. (2006). Differentiation of human adult CD34+ stem cells into cells with a neural phenotype: role of astrocytes. Exp Neurol 197: 399-406.

REIDY, K.J., VILLEGAS, G., TEICHMAN, J., VERON, D., SHEN, W., JIMENEZ, J., THOMAS, D. and TUFRO, A. (2009). Semaphorin3a regulates endothelial cell number and podocyte differentiation during glomerular development. Development 136: 3979-3989.

RISSONEA, MONOPOLI M, BELTRAME M, BUSSOLINO F, COTELLI F and ARESE M. (2007). Comparative genome analysis of the neurexin gene family in Danio rerio: insights into their functions and evolution. Mol. Biol. Evol. 24: 236-252.

RISSONE, A., SANGIORGIO, L., MONOPOLI, M., BELTRAME, M., ZUCCHI, I., BUSSOLINO, F., ARESE, M. and COTELLI, F. (2010). Characterization of the Neuroligin Gene Family Expression and Evolution in Zebrafish. Dev. Dyn. 239: 688-702.

RUIZ DE ALMODOVAR, C., LAMBRECHTS, D., MAZZONE, M. and CARMELIET, P. (2009). Role and therapeutic potential of VEGF in the nervous system. Physiol Rev 89: 607-648.

SCHEIFFELE, P., FAN, J., CHOIH, J., FETTER, R. and SERAFINI, T. (2000). Neuroligin expressed in nonneuronal cells triggers presynaptic development in contacting axons. Cell 101: 657-669.

SERINI, G. and BUSSOLINO, F. (2004). Common cues in vascular and axon guidance. Physiology (Bethesda) 19: 348-354.

SERINI, G., NAPIONE, L. and BUSSOLINO, F. (2008). Integrins team up with tyrosine kinase receptors and plexins to control angiogenesis. Curr Opin Hematol 15: 235-242.

SERINI, G., VALDEMBRI, D., ZANIVAN, S., MORTERRA, G., BURKHARDT, C., CACCAVARI, F., ZAMMATARO, L., PRIMO, L., TAMAGNONE, L., LOGAN, M. et al., (2003). Class 3 semaphorins control vascular morphogenesis by inhibiting integrin function. Nature 424: 391-397.

SHENG, M. and HOOGENRAAD, C.C. (2007). The postsynaptic architecture of excitatory synapses: a more quantitative view. Annu. Rev. Biochem. 76: 823-847.

SIERRA, J.R., CORSO, S., CAIONE, L., CEPERO, V., CONROTTO, P., CIGNETTI, A., PIACIBELLO, W., KUMANOGOH, A., KIKUTANI, H., COMOGLIO, P.M. et al., (2008). Tumor angiogenesis and progression are enhanced by Sema4D produced by tumor-associated macrophages. J Exp Med 205: 1673-1685.

SONG, J.Y., ICHTCHENKO, K., SUDHOF, T.C. and BROSE, N. (1999). Neuroligin 1 is a postsynaptic cell-adhesion molecule of excitatory synapses. Proc. Natl Acad. Sci. USA 96: 1100-1125.

STRASSER, G.A., KAMINKER, J.S. and TESSIER-LAVIGNE, M. (2010). Microarray analysis of retinal endothelial tip cells identifies CXCR4 as a mediator of tip cell morphology and branching. Blood 115: 5102-5110.

SUDHOF, T.C. (2001). alpha-Latrotoxin and its receptors: neurexins and CIRL/ latrophilins. Annu Rev Neurosci 24: 933-962.

SUDHOF, T.C. (2008). Neuroligins and neurexins link synaptic function to cognitive disease. Nature 455: 903-911.
SUGITA, S. (2001). A stoichiometric complex of neurexins and dystroglycan in brain J. Cell Biol. 154: 435-445.

SZATMARI, P.PATERSON, A.D.ZWAIGENBAUM, L.ROBERTS, W.BRIAN, J.LIU, X.Q.VINCENT, J.B.SKAUG, J.L.THOMPSON, A.P.SENMAN, L. et al., (2007) Mapping autism risk loci using genetic linkage and chromosomal rearrangements. Nat Genet 39: 319-328.

TABUCHI, K. and SUDHOF, T.C. (2002). Structure and evolution of neurexin genes: insight into the mechanism of alternative splicing. Genomics 79: 849-859.

TANIGUCHI, M., YUASA, S., FUJISAWA, H., NARUSE, I., SAGA, S., MISHINA, M. and YAGI, T. (1997). Disruption of semaphorin III/D gene causes severe abnormality in peripheral nerve projection. Neuron 19: 519-530.

TORRES-VAZQUEZ, J., GITLER, A.D., FRASER, S.D., BERK, J.D., VAN, N.P., FISHMAN, M.C., CHILDS, S., EPSTEIN, J.A. and WEINSTEIN, B.M. (2004). Semaphorin-plexin signaling guides patterning of the developing vasculature. Dev Cell 7: 117-123.

VACCA, A., SCAVELLI, C., SERINI, G., DI PIETRO, G., CIRULLI, T., MERCHIONNE, F., RIBATTI, D., BUSSOLINO, F., GUIDOLIN, D., PIAGGIO, G. et al., (2006). Loss of inhibitory semaphorin $3 \mathrm{~A}$ (SEMA3A) autocrine loops in bone marrow endothelial cells of patients with multiple myeloma. Blood 108: 1661-1667.

VANDERBORGHT, K., KOBOR-NYAKAS, D.E., KLAUKE, K., EGGEN, B.J., NYAKAS, C., VAN DER ZEE, E.A. and MEERLO, P. (2009). Physical exercise leads to rapid adaptations in hippocampal vasculature: Temporal dynamics and relationship to cell proliferation and neurogenesis. Hippocampus 19: 928-936.

VAROQUEAUX, F. (2006). Neuroligins determine synapse maturation and function. Neuron 51: 741-754

VESTWEBER, D. (2002). Regulation of endothelial cell contacts during leukocyte extravasation. Curr Opin Cell Biol 14: 587-593.

VIEIRA, J.M., SCHWARZ, Q. and RUHRBERG, C. (2007). Selective requirements for NRP1 ligands during neurovascular patterning. Development 134: 1833-4183.

WILSON, H.L. (2003). Molecular characterisation of the $22 \mathrm{q} 13$ deletion syndrome supports the role of haploinsufficiency of SHANK3/PROSAP2 in the major neurological symptoms. J. Med. Genet. 40: 575-584.

WURMSER, A.E., NAKASHIMA, K., SUMMERS, R.G., TONI, N., D'AMOUR, K.A., LIE, D.C. and GAGE, F.H. (2004). Cell fusion-independent differentiation of neural stem cells to the endothelial lineage. Nature 430: 350-356.

YARON, A., HUANG, P.H., CHENG, H.J. and TESSIER-LAVIGNE, M. (2005). Differential requirement for Plexin-A3 and -A4 in mediating responses of sensory and sympathetic neurons to distinct class 3 Semaphorins. Neuron 45: 513-523.

ZACCHIGNA, S., LAMBRECHTS, D. and CARMELIET, P. (2008). Neurovascular signalling defects in neurodegeneration. Nat Rev Neurosci 9: 169-181.

ZHANG, Y., SINGH, M.K., DEGENHARDT, K.R., LU, M.M., BENNETT, J., YOSHIDA, Y. and EPSTEIN, J.A. (2009). Tie2Cre-mediated inactivation of plexinD1 results in congenital heart, vascular and skeletal defects. Dev Biol 325: 82-93.

ZILBOVICIUS, M., BODDAERT, N., BELIN, P., POLINE, J.B., REMY, P., MANGIN, J.F., THIVARD, L., BARTHELEMY, C. and SAMSON, Y. (2000). Temporal lobe dysfunction in childhood autism: a PET study. Positron emission tomography. Am J Psychiatry 157: 1988-1993. 


\section{Further Related Reading, published previously in the Int. J. Dev. Biol.}

Insulin-like growth factor-2 regulates early neural and cardiovascular system development in zebrafish embryos

Lori Hartnett, Catherine Glynn, Catherine M. Nolan, Maura Grealy and Lucy Byrnes

Int. J. Dev. Biol. (2010) 54: 573-583

The seminal work of Werner Risau in the study of the development of the vascular system

Domenico Ribatti

Int. J. Dev. Biol. (2010) 54: 567-572

Estrogen regulation of placental angiogenesis and fetal ovarian development during primate pregnancy

Eugene D. Albrecht and Gerald J. Pepe

Int. J. Dev. Biol. (2010) 54: 397-407

Uteroplacental vascular development and placental function: an update

Lawrence P. Reynolds, Pawel P. Borowicz, Joel S. Caton, Kimberly A. Vonnahme, Justin S. Luther, David S. Buchanan, Shireen A. Hafez, Anna T. Grazul-Bilska and Dale A. Redmer

Int. J. Dev. Biol. (2010) 54: 355-365

Embryonic development of the proepicardium and coronary vessels Anna Ratajska, Elzbieta Czarnowska and Bogdan Ciszek

Int. J. Dev. Biol. (2008) 52: 229-236

Vasculogenesis and angiogenesis in the mouse embryo studied using quail/mouse chimeras Michel Pudliszewski and Luc Pardanaud

Int. J. Dev. Biol. (2005) 49: 355-361

$$
\text { Impact Factor }(2010)=\mathbf{2 . 8 6}
$$

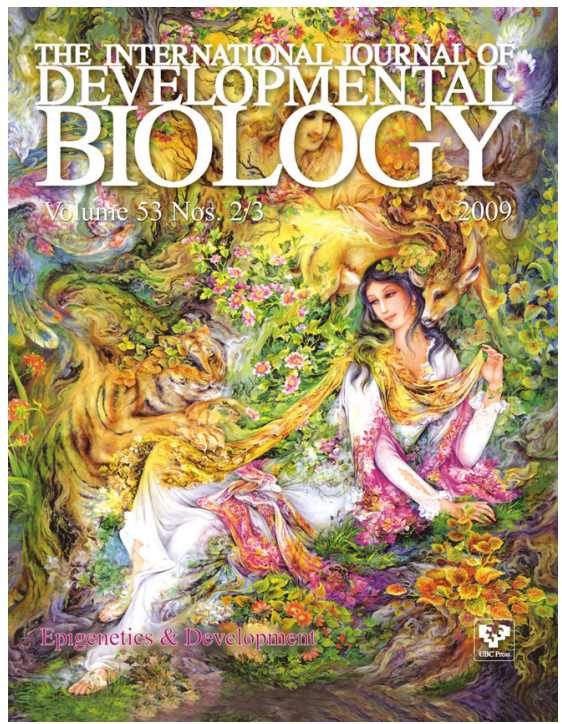

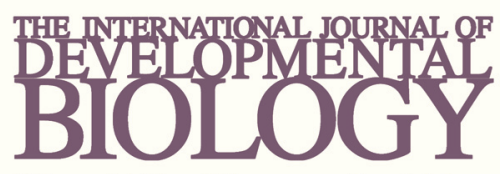

Volume 54 Nos. 6/7
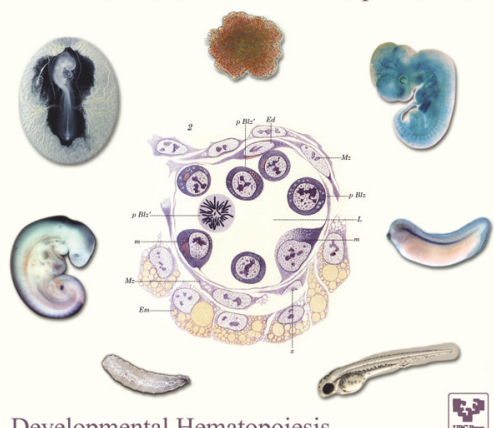

Developmental Hematopoiesis

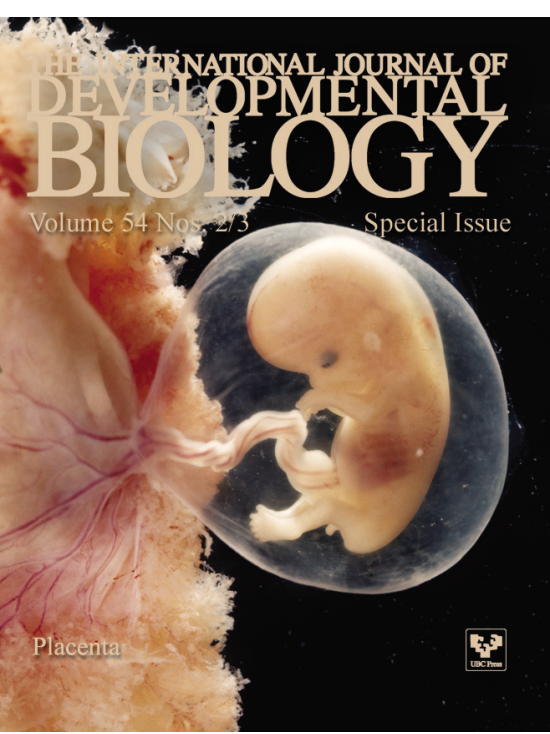

